\title{
Genotypes of Giardia duodenalis in Household Dogs and Cats from Poland
}

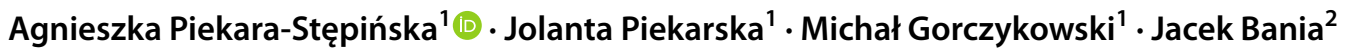

Received: 17 June 2020 / Accepted: 28 September 2020 / Published online: 11 October 2020

(c) The Author(s) 2020

\begin{abstract}
Background Giardia duodenalis is a widespread protozoan parasite affecting humans and many species of animals, including dogs and cats. Due to its zoonotic potential, it is important to know the frequency of this parasite in companion animals. The aim of this study was to determine current epidemiological status of G. duodenalis in household dogs and cats.

Methods In this study, 293 fecal samples from pet dogs and cats were collected from January 2017 to July 2019 and tested for $G$. duodenalis by PCR (using $\beta$-giardin gene). The animals were divided into groups depending on their age, breed and fecal consistency.

Results The examination allowed for detection of G. duodenalis in $6.0 \%$ of canine and $3.9 \%$ of feline fecal samples. The highest frequency was revealed in young (under one-year old) dogs. Sequencing confirmed the presence of assemblages $\mathrm{C}$ and $\mathrm{D}$ in $\operatorname{dog}$ s and $\mathrm{A}$ and $\mathrm{F}$ in cats.

Conclusion The study showed current frequency of G. duodenalis in dogs and cats and also revealed the occurrence of hostspecific assemblages as well as zoonotic assemblage $\mathrm{A}$.
\end{abstract}

Keywords Nested PCR $\cdot \beta$-Giardin $\cdot$ Protozoa $\cdot$ Zoonosis

\section{Introduction}

Dogs and cats are intimate companion animals of humans. According to data from 2019, there are over seven million dogs and over six million cats in Poland [40]. Despite numerous advantages of having a pet, close contact between humans and dogs or cats can result in zoonotic diseases. Important factors causing zoonotic diseases are parasites, such as Giardia duodenalis, Cryptosporidium spp., Echinococcus spp., Dipylidium caninum or Toxocara spp.

Giardia duodenalis (also known as Giardia intestinalis or Giardia lamblia) is a unicellular protozoan parasite affecting humans and many animal species. There are two

Agnieszka Piekara-Stępińska

agnieszka.piekara@upwr.edu.pl

1 Division of Parasitology, Department of Internal Medicine and Clinic of Diseases of Horses, Dogs and Cats, Wrocław University of Environmental and Life Sciences, CK Norwida 31, 50-375 Wrocław, Poland

2 Department of Food Hygiene and Consumer Health Protection, Wrocław University of Environmental and Life Sciences, CK Norwida 31, 50-375 Wrocław, Poland morphological stages of $G$. duodenalis: a trophozoite and a cyst (infective stage). The parasite can colonize the upper small intestine but it was also found in the lower small intestine, stomach, colon and biliary tract $[3,7]$. G. duodenalis transmission occurs via fecal-oral route (from contaminated water or food and directly from infected individuals) [5]. Giardiasis in dogs and cats can include diarrhea and weight loss or the disease can be asymptomatic.

In recent years, the infection rate of $G$. duodenalis in Europe ranged from $0.8 \%$ (Switzerland) to $42 \%$ (Germany) and from $5.9 \%$ (Spain) to $20.5 \%$ (Greece) in dogs and cats, respectively [11, 21, 31, 42].

Studies conducted in Poland between 2006 and 2017 revealed the frequency of $G$. duodenalis to range from 2 to $36 \%$ in dogs and from 3.2 to $15.1 \%$ in cats, depending on the examined population, geographical origin of the animal, and diagnostic methods (Table 1). The assemblages detected so far in Poland are B, C, D in dogs and A, B, D, F in cats. However, due to small areas covered by the previous studies, their outcomes did not reflect epidemiological situation for the entire area of Poland [4, 19, 29, 34, 43].

Since 2004 giardiasis has been considered by WHO a neglected disease [32]. Human giardiasis can be 
Table 1 Giardia duodenalis in dogs and cats in Poland, 2006-2017

\begin{tabular}{|c|c|c|c|c|c|c|c|}
\hline Area of Poland & Populations & $\begin{array}{l}\text { No. of examined } \\
\text { samples }\end{array}$ & $\begin{array}{l}\text { No. of positive } \\
\text { samples }\end{array}$ & $\begin{array}{l}\text { Infection rate } \\
(\%)\end{array}$ & Method & $\begin{array}{l}\text { Assemblages (if } \\
\text { examined) }\end{array}$ & References \\
\hline \multicolumn{8}{|l|}{ Dogs } \\
\hline \multirow[t]{2}{*}{ Warsaw } & \multirow[t]{2}{*}{ Owned } & \multirow[t]{2}{*}{350} & 18 & 5.14 & Microscopy & A-I, C, D & [43] \\
\hline & & & - & 9.14 & PCR & & \\
\hline Unknown & Sled & 64 & - & 35.9 & IFA & & [4] \\
\hline \multirow{2}{*}{$\begin{array}{l}\text { West-central region } \\
\text { of Poland }\end{array}$} & Sheltered & 88 & 2 & 2.3 & \multirow[t]{2}{*}{ Microscopy $^{\mathrm{a}}$} & \multirow[t]{2}{*}{ C, D } & \multirow[t]{2}{*}[34]{} \\
\hline & Owned & 60 & 1 & 1.6 & & & \\
\hline Wroclaw & Owned & 128 & 27 & 21.1 & PCR (bg) & B, C, D & [29] \\
\hline \multicolumn{8}{|l|}{ Cats } \\
\hline Warsaw & Household & 160 & 6 & 3.75 & Microscopy $^{\mathrm{a}}$ & A, B, D & [19] \\
\hline Wroclaw & Owned & 33 & 5 & 15.1 & PCR (bg) & $\mathrm{F}, \mathrm{A}$ & [29] \\
\hline \multirow[t]{2}{*}{ Unknown } & Pet & 31 & 1 & - & PCR & $\mathrm{F}$ & {$[22]$} \\
\hline & stray & 33 & 2 & - & & $\mathrm{F}$ & \\
\hline
\end{tabular}

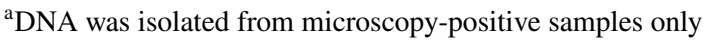

asymptomatic or can cause persistent diarrhea or malabsorption associated with body weight loss [13].

G. duodenalis includes eight morphologically indistinguishable assemblages (A-H). The assemblages A and B are further divided into sub-genotypes AI, AII, AIII, BIII and BIV. Typical genotypes in $\operatorname{dog}$ s are $\mathrm{C}$ and $\mathrm{D}$, but $\mathrm{A}$ and $\mathrm{B}$ can also be found, and exceptionally even $\mathrm{E}$ and $\mathrm{F}$ ones $[6,9,12,14,20]$. Genotype $\mathrm{F}$ is common in cats, which can be infected also by genotype A, E and rarely $C[6,21,24]$. Humans are almost exclusively infected by assemblages $\mathrm{A}$ and $\mathrm{B}$ but genotypes $\mathrm{C}, \mathrm{D}, \mathrm{E}$ and $\mathrm{F}$ were also found in rare cases $[1,6,14,30,37]$.

Microscopic studies using fecal flotation enable detection of the cysts [35]. Other diagnostic methods involve detection of coproantigen, usually by ELISA. PCR techniques, based on the amplification of gene fragments encoding SSU rRNA, glutamate dehydrogenase $(g d h)$, triosephosphate isomerase (tpi) or $\beta$-giardin ( $b g$ ), allow for detection of Giardia DNA and also for genotyping [15, 26]. Although the multilocus genotyping is considered the most useful, genotyping based on single locus with high sequence heterogeneity (such as $b g$ or $t p i$ ) is commonly accepted, especially where the diagnosis is extended to the sequencing of the obtained PCR products $[23,36]$. One of the most commonly used markers is $\beta$-giardin, which allows for a successful detection of the parasite by PCR and also enables genotyping and subgenotyping of assemblage A [5, 23]. $\beta$-giardin allows also for identification of mixed invasions, especially in the case of two-way analysis of the obtained sequences [31]. Moreover, one of the most sensitive and specific methods for detection of Giardia spp. is immunofluorescence and it is considered a reference standard assay for the detection of this parasite in dogs and cats feces [16, 38].
Due to the zoonotic potential of G. duodenalis, it is particularly important to determine its current infection rate in domestic animals. The overall prevalence and frequency of $G$. duodenalis genotypes in dogs and cats can indicate the potential risk of invasion in humans. The aim of this study was to run a molecular detection of $G$. duodenalis in fecal samples and to assess its overall frequency broken into frequency of each genotype in household dogs and cats from Poland.

\section{Methods}

\section{Study area and sample collection}

A total of 293 fresh fecal samples were obtained between January 2017 and July 2019 from individual, randomly chosen household dogs (217 samples) and cats (76 samples) living in different regions of Poland. The area of Polish territory is over 312,000 square kilometers divided into 16 provinces. The examined samples came from nine provinces (Pomerania, Greater Poland, Lower Silesia, Opolskie Voivodship, Silesia, Lodzkie Voivodship, Holy Cross, Lesser Poland, Subcarpathian), which account for nearly 153,000 square kilometers (about $50 \%$ of the country area) (Fig. 1). The samples, collected by pet owners, were placed individually into disposable plastic bags. The age of the animals ranged from nine weeks to eleven years. They were grouped based on the age (under one-year old, over one-year old), breed and feces consistency (formed, unformed). About $1 \mathrm{~g}$ of each sample was frozen at $-80^{\circ}$ $\mathrm{C}$ for further analysis. 


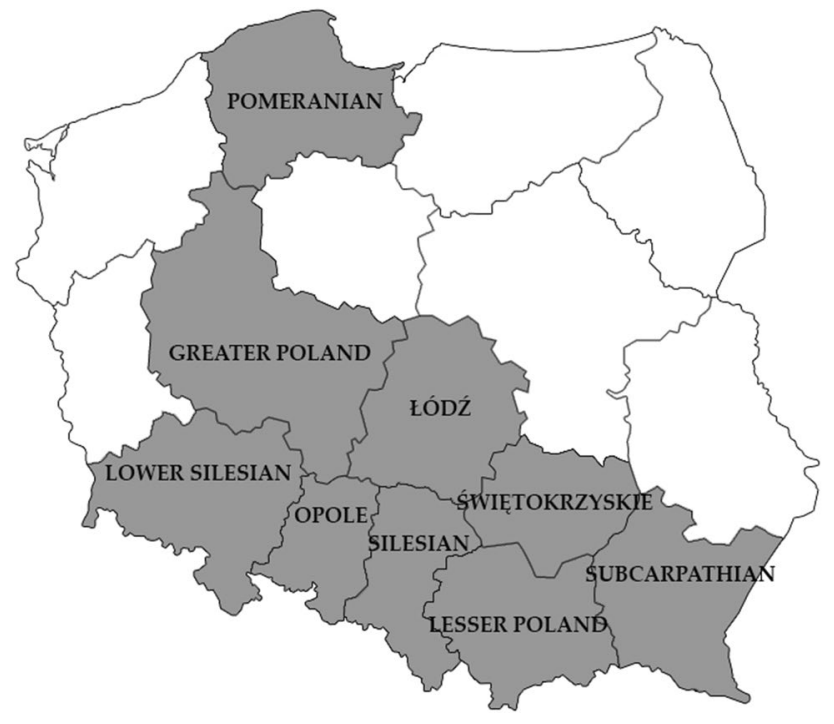

Fig. 1 Map of Poland. Dark grey areas (voivodeships) represent the origin of the tested canine fecal samples. Images used are in the public domain and were downloaded from: https://pl.wikipedia.org/wiki/ Plik:Polska_kontur_bialy.png

\section{DNA extraction}

DNA was isolated from $100 \mathrm{mg}$ of each fecal sample using Genomic Mini AX Stool (A\&A Biotechnology, Poland) as per the manufacturer's instruction. The DNA samples were stored at $-80{ }^{\circ} \mathrm{C}$ until further use.

\section{PCR amplification}

To identify $G$. duodenalis in the stool samples, fragments covering $\beta$-giardin gene were amplified by nested PCR. The amplification of a $763 \mathrm{bp}$ region was carried out using a forward primer G7 (5'AAGCCCGACGACCTCACCCGCAGT GC3') and a reverse primer G759 (5'GAGGCCGCCCTG GATCTTCGAGACGAC3'). For secondary PCR, 587 bp fragment was amplified using $1 \mu \mathrm{l}$ of the first PCR product. The secondary PCR was carried out using nested forward 511 (5' GAACGAACGAGATCGAGGTCCG'3) and nested reverse 511 (5' CTCGACGAGCTTCGTGTT 3'). The mixture composition and PCR conditions were described by Lalle et al. (2005) [23]. PCR mix consisted of a buffer containing $1.5 \mathrm{mM} \mathrm{MgCl} 2,200 \mathrm{mM}$ of each dNTP (dNTP mix 10, A\&A Biotechnology, Gdynia, Poland) 10 pmol of each primer, 2.5 units of RUN DNA polymerase (A\&A Biotechnology, Gdynia, Poland) and $3 \mu \mathrm{l}(1 \mu \mathrm{l}$ in secondary PCR) of purified DNA in a final volume of $25 \mu \mathrm{l}$. PCR was performed using a thermocycler BioRad T100 ${ }^{\mathrm{TM}}$ Thermal Cycler. Primary PCR conditions were as follows: $95{ }^{\circ} \mathrm{C}$ for $5 \mathrm{~min}$ for $1 \mathrm{cycle}, 95^{\circ} \mathrm{C}$ for $30 \mathrm{~s}, 50^{\circ} \mathrm{C}$ for $30 \mathrm{~s}$ and $72{ }^{\circ} \mathrm{C}$ for $1 \mathrm{~min}$ for 40 cycles followed by $72^{\circ} \mathrm{C}$ for $7 \mathrm{~min}$. Secondary
PCR conditions were: $96{ }^{\circ} \mathrm{C}$ for $5 \mathrm{~min}$ for 1 cycle, $96{ }^{\circ} \mathrm{C}$ for $45 \mathrm{~s}, 55{ }^{\circ} \mathrm{C}$ for $30 \mathrm{~s}$ and $72{ }^{\circ} \mathrm{C}$ for $45 \mathrm{~s}$ for 35 cycles followed by $72{ }^{\circ} \mathrm{C}$ for $7 \mathrm{~min}$. The secondary PCR products were examined electrophoretically in $2 \%$ agarose gels and visualized after staining with Midori Green Advance DNA Stain (Genetics, Germany).

\section{DNA sequencing and data analysis}

PCR products purification and sequencing was performed by Genomed (Poland) in both directions. The resulting chromatograms were visually assessed to exclude the presence of double peaks. The obtained sequences were compared by a blast search (https://blast.ncbi.nlm.nih.gov/Blast.cgi) with sequences deposited in GenBank. Phylogenetic analysis was performed using neighbor-joining method with MEGA 4 free software. Evaluation of the reliability of the clusters was confirmed using Bootstrap values (1000 replicates). Reference sequences used in the phylogenetic tree were: AB508814.1 for assemblage A; MN270296.1, KX757753.1 for assemblage C; JN416550.1, JN416548.1, JN416559.1 and LC316659.1 for assemblage D and LC341557.1 for assemblage F.

\section{Statistical analysis}

The frequency of G. duodenalis infections presented in the tables shows the percentage of positive samples in the studied population. We also provided confidence intervals (CI) at the level of $95 \%(p=0.05)$, calculated according to the Wilson method. The chi-square test $\left(\chi^{2}\right)$ with Yates correction implemented in STATISTICA ver. 12.0 software package was used to compare the differences in Giardia infection rates among the investigated groups. Differences were considered significant at $p \leq 0.05$.

\section{Results}

The presence of $G$. duodenalis DNA was detected in $13 / 217(6.0 \%)$ canine and in 3/76 (3.9\%) feline fecal samples. Higher frequency of the infection was observed in dogs under 1 year old $(13 / 107,12.2 \%)(p<0.05)$. Among the dog breeds, Giardia infections were most frequently observed in French bulldogs ( 4 out of 16; $25 \%$ ), and the infection rate was significantly higher than in other breeds $(p<0.05)$. There were no statistically significant differences connected with age and breed in cats or fecal consistency in both species (Table 2). All 16 PCR-positive samples were successfully sequenced. In dogs, 10 isolates were the closest to assemblage D (77\%) and 3 to assemblage $\mathrm{C}(23 \%)$. In cats, two were the closest to assemblage F (67\%), and one to assemblage A (33\%). Detailed data 
Table 2 Occurrence of Giardia duodenalis in dogs and cats in relation to clinical symptoms

\begin{tabular}{|c|c|c|c|c|c|c|c|}
\hline Animal species (n) & Feces condition $(n)$ & $\begin{array}{l}\text { No. of } \\
\text { positive } \\
\text { animals }\end{array}$ & $\begin{array}{l}\text { Infection frequency } \\
\left(\mathrm{CI}^{\mathrm{a}}\right)\end{array}$ & Sample symbol & $\begin{array}{l}\text { Animal } \\
\text { age } \\
\text { (months) }\end{array}$ & Animal breed & $\begin{array}{l}\text { Giardia } \\
\text { geno- } \\
\text { type }\end{array}$ \\
\hline \multirow[t]{13}{*}{$\operatorname{Dog}(217)$} & \multirow[t]{3}{*}{ Formed (64) } & \multirow[t]{3}{*}{3} & \multirow[t]{3}{*}{$4.7(1.6-12.9)$} & DV80 & 3 & $\begin{array}{l}\text { West Highland White } \\
\text { Terrier }\end{array}$ & $\mathrm{D}$ \\
\hline & & & & G32 & 2 & $\begin{array}{l}\text { American Staffordshire } \\
\text { Terrier }\end{array}$ & $\mathrm{D}$ \\
\hline & & & & D99 & 9 & $\begin{array}{l}\text { Greater Swiss Moun- } \\
\text { tain Dog }\end{array}$ & $\mathrm{D}$ \\
\hline & \multirow[t]{10}{*}{ Unformed (153) } & \multirow[t]{10}{*}{10} & \multirow[t]{10}{*}{$6.5(3.6-11.6)$} & G67 & 2 & French bulldog & $\mathrm{D}$ \\
\hline & & & & D124 & 5 & French bulldog & $\mathrm{D}$ \\
\hline & & & & DV67 & 9 & Siberian Husky & $\mathrm{D}$ \\
\hline & & & & G30 & 6 & Dachshund & $\mathrm{D}$ \\
\hline & & & & G102 & 2 & German Shepherd & $\mathrm{D}$ \\
\hline & & & & G127 & 3 & Siberian Husky & $\mathrm{D}$ \\
\hline & & & & G203 & 2 & French bulldog & $\mathrm{D}$ \\
\hline & & & & G198 & 3 & French bulldog & $\mathrm{C}$ \\
\hline & & & & G205 & 2 & German Shepherd & $\mathrm{C}$ \\
\hline & & & & G15 & 2 & Berger Blanc Suisse & $\mathrm{C}$ \\
\hline \multirow[t]{3}{*}{ Cat (76) } & \multirow[t]{2}{*}{ Formed (34) } & \multirow[t]{2}{*}{2} & \multirow[t]{2}{*}{$5,9 \%(0.7-19.7)$} & DV74 & 4 & Exotic Shorthair & A \\
\hline & & & & G217 & 6 & Mixed breed & $\mathrm{F}$ \\
\hline & Unformed (42) & 1 & $2.4 \%(0.1-12.6)$ & G87 & 13 & Mixed breed & $\mathrm{F}$ \\
\hline
\end{tabular}

${ }^{\mathrm{a}} \mathrm{CI}=95 \%$ confidence interval according to the modified (adjusted) Wald method

are included in Table 3. The phylogenetic relationship of Giardia isolates and reference sequences for A, C, D and $\mathrm{F}$ assemblages are showed in Fig. 2.

\section{Discussion}

The occurrence of G. duodenalis in dogs and cats depends mainly on the examined area but also on the diagnostic methods or examined groups (different living condition or age). In this study, the frequency of $G$. duodenalis found
Table 3 Comparison of Giardia duodenalis isolates (genotyping $\beta$-giardin gene) in dogs and cats in Poland

\begin{tabular}{llllll}
\hline Host & Assemblage & Sample & Reference sequence & Stretch & SNPs \\
\hline Dog & D & G67 & JN416559.1 & $45-471$ & None \\
Dog & D & G203 & JN416559.1 & $45-471$ & None \\
Dog & D & D124 & JN416559.1 & $45-471$ & T115C \\
Dog & D & G32 & JN416559.1 & $45-471$ & T115C \\
Dog & D & DV67 & JN416559.1 & $45-471$ & T115C \\
Dog & D & DV80 & JN416559.1 & $45-471$ & A67T, G109A, T115C \\
Dog & D & G30 & JN416559.1 & $45-471$ & T115C \\
Dog & D & G102 & JN416559.1 & $45-471$ & T115C \\
Dog & D & G127 & JN416559.1 & $45-471$ & G109A, T115C \\
Dog & D & D99 & JN416559.1 & $45-471$ & G109A, T115C \\
Dog & C & G205 & KX757753.1 & $64-410$ & None \\
Dog & C & D198 & KX757753.1 & $64-410$ & G175C, T207C \\
Dog & C & G15 & KX757753.1 & $64-410$ & T207C \\
Cat & A & DV74 & AB508814.1 & $97-559$ & T419C \\
Cat & F & G217 & LC341557.1 & $20-452$ & T100C, T268C \\
Cat & F & G87 & LC341557.1 & $20-452$ & T49G, T100C \\
\hline
\end{tabular}


Fig. 2 Phylogenetic relationship between Giardia duodenalis isolates collected from dogs and cats, based on sequences of $\beta$-giardin locus, determined by the neighbor-joining method, using Kimura-2 parameter model. Each branch shows bootstrap values. Reference sequences with their accession numbers in GenBank are provided. Sequence of Giardia muris was used as outgroup

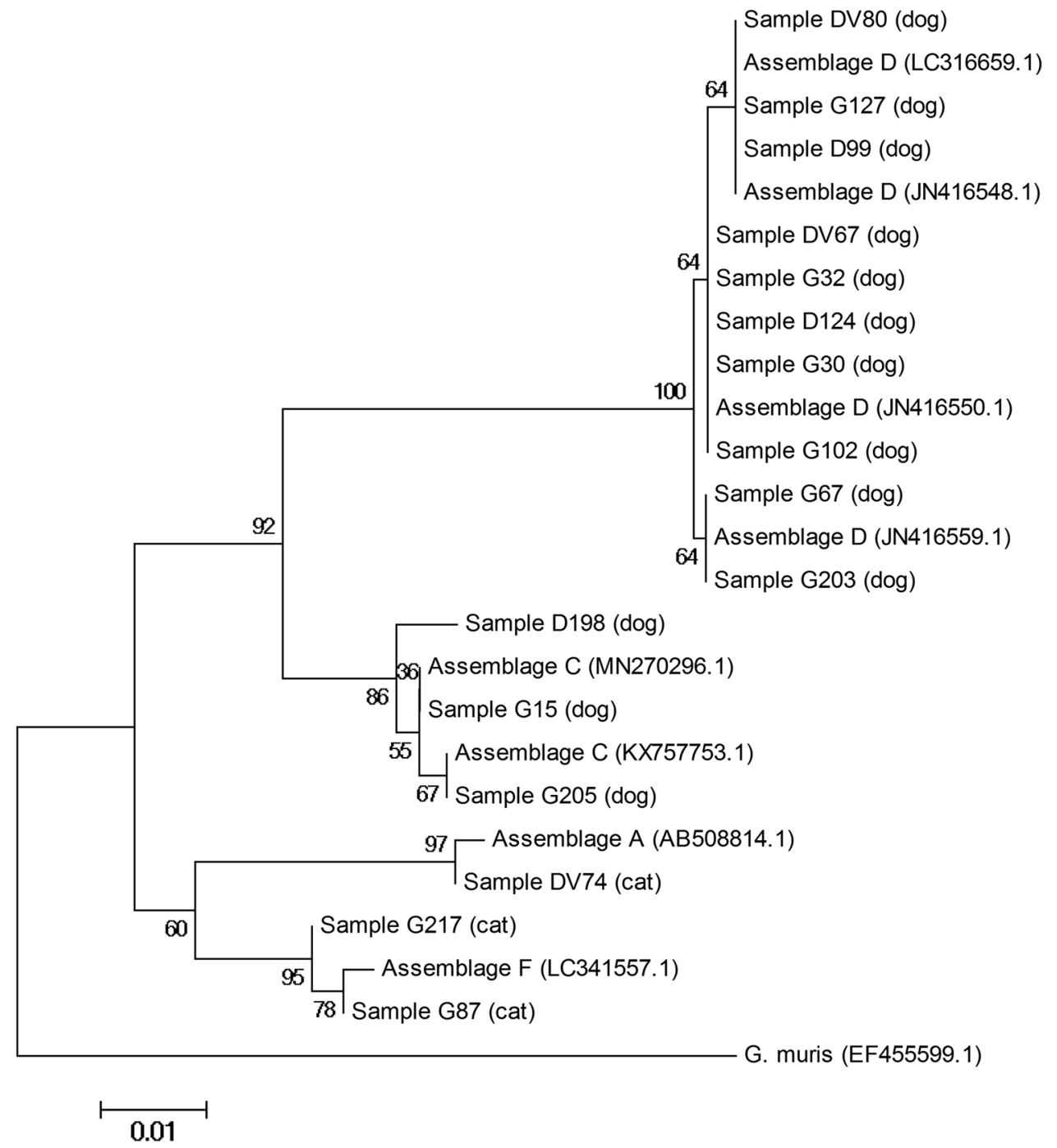

in fecal samples of dogs from different regions of Poland was $6.0 \%$ and this result fell within the lower limit of previous results from Poland [4, 29, 34, 43]. Assessment of this frequency was based on amplification of $b g$ locus, a highly sensitive and widely recommended marker [9, 23]. However, some authors reported that DNA amplification can be difficult due to PCR inhibitors in feces [38]. Our study showed lower percentage of positive samples (6\%) than some other recent publications on household dogs in Europe involving molecular methods (29\% in Spain, $12.9 \%$ in Greece, $42 \%$ in Germany) [11, 21, 31]. High frequency of Giardia noted in Germany can be connected with lower number of examined samples and this result cannot be representative for the entire country. In our study, significantly higher frequency of the parasite was noted in young dogs, under one-year old (14\%). The age of the dogs seems to be an important risk factor for $G$. duodenalis, as previously described. A recent study conducted by Pan et al. (2018), based on amplification of $b g$ and $t p i$ genes, showed significantly higher detection rate of Giardia in young (16.1\%) than in adult dogs (7.6\%) [28]. Shin et al. (2015) also used $b g$ gene as a molecular marker and confirmed significantly higher prevalence in young, sheltered dogs [33]. We found no cases of G. duodenalis in the dogs over one-year old, however, many studies detected the presence of this parasite also in adult dogs $[21,28]$. Among the examined breeds, French bulldogs were the most often affected by the parasite. This breed is commonly considered to be predisposed to many diseases, especially connected with respiratory and reproductive systems [27]. There are many opinions about pathogenicity of giardiasis in both humans and animals. Mochizuky et al. (2001) noticed almost equal frequency of $G$. duodenalis in symptomatic and asymptomatic dogs [25]. We found no statistically significant differences connected with fecal consistency in the examined groups, however, some authors showed higher prevalence of the parasite in diarrheic dogs. For example, higher prevalence of $G$. 
duodenalis in household dogs with loose consistency of feces (all dogs older than 6 months) was reported by Ulterwijk et al. (2019), but in other groups of dogs (sheltered or hunting), significant differences were not observed [17, $33,41]$.

In the current study, G. duodenalis was found in 3.9\% of feline fecal samples. These results were similar to those obtained in household cats from Spain (5.9\%), but lower than in Germany (14\%) and Greece (15.6\%) [11, 21, 31]. We found no statistically significant differences regarding age, breed or fecal condition in cats.

In dogs, we confirmed only host-specific genotypes D (77\% of positive samples) and C (23\% of positive samples). This differed significantly from the results previously described for western Poland, where mostly genotype C, and just a few cases of genotypes D and B were detected [29]. The occurrence of only genotype D in Poland was reported for central and western part of the country, although there were only two specimens sequenced (34). In other European countries, dog-specific genotypes were found with the highest frequency, but in some areas genotypes $\mathrm{A}$ and $\mathrm{B}$, and in rare cases, $\mathrm{E}$ and $F$ were also detected [2, 21, 31, 35]. In northern Spain, assemblages A and B were found even more often than dog-specific genotypes [17]. In cats, we found feline-specific assemblage $\mathrm{F}(67 \%)$, but also assemblage $\mathrm{A}$ (33\%). The previous study from Poland also showed occurrence of these genotypes [29]. In some countries neighboring Poland (Germany, Czech Republic or Slovak Republic), genotype $\mathrm{F}$ was the prevailing or the only one [22, 35]. Contrary to that, examination of feline fecal samples from Greece revealed mostly genotype $\mathrm{A}$ and rare cases of assemblages F, but also B and C [21]. The role of companion animals as a source of human giardiasis was widely discussed. Some papers showed that dogs and cats do not seem to play an important role as reservoirs of zoonotic genotypes and transmission from these animals to humans is rare [11,31]. However, other studies proved that also genotypes A or B can be common in pet animals, what suggests potential zoonotic risk and possible consequences for human health [10, 18]. Also, Traub et al. (2004) showed strong association between giardiasis in humans and dogs from the same community [39]. Zoonotic risk seems to be different in various areas and should be assessed in each region.

In summary, fecal samples of dogs and cats from different regions of Poland were collected and PCR examination based on $\beta$-giardin locus amplification was conducted. This examination confirmed the occurrence of $G$. duodenalis genotypes specific for dogs or cats and also the occurrence of zoonotic genotype A in cats. The study confirmed that giardiasis in dogs is strongly connected with their age and is often diagnosed in dogs under one-year old. Moreover, $G$. duodenalis was found more often in French bulldogs than in the dogs of other breeds, which according to our knowledge is the first communication of such a result.

Acknowledgements This research was supported by statutory research and development activity funds from the Minister of Science and Higher Education assigned to the Faculty of Veterinary Medicine, Wroclaw University of Environmental and Life Sciences.

\section{Compliance with Ethical Standards}

Conflict of interest The authors declare that they have no conflict of interest.

Open Access This article is licensed under a Creative Commons Attribution 4.0 International License, which permits use, sharing, adaptation, distribution and reproduction in any medium or format, as long as you give appropriate credit to the original author(s) and the source, provide a link to the Creative Commons licence, and indicate if changes were made. The images or other third party material in this article are included in the article's Creative Commons licence, unless indicated otherwise in a credit line to the material. If material is not included in the article's Creative Commons licence and your intended use is not permitted by statutory regulation or exceeds the permitted use, you will need to obtain permission directly from the copyright holder. To view a copy of this licence, visit http://creativecommons.org/licenses/by/4.0/.

\section{References}

1. Abd El-Latif NF, El-Taweel HA, Gaballah A, Salem AI, Abd El-Malek AHM (2020) Molecular characterization of Giardia intestinalis detected in humans and water samples in Egypt. Acta Parasitol 65(2):482-489. https://doi.org/10.2478/s11686-02000176-4

2. Adell-Aledón M, Köster PC, de Lucio A et al (2018) Occurrence and molecular epidemiology of Giardia duodenalis infection in dog populations in eastern Spain. BMC Vet Res 14(1):26. https:// doi.org/10.1186/s12917-018-1353-Z

3. Araki H, Shimizu S, Hayashi K et al (2017) Acute acalculous cholecystitis caused by Giardia lamblia. Intern Med 56(13):16571662. https://doi.org/10.2169/internalmedicine.56.8087

4. Bajer A, Bednarska M (2007) Cryptosporidium spp. and Giardia spp. infections in sled dogs, Medycyna Weterynaryjna, 63 (6) (in Polish)

5. Ballweber LR, Xiao L, Bowman DD, Kahn G, Cama VA (2010) Giardiasis in dogs and cats: update on epidemiology and public health significance. Trends Parasitol 26(4):180-189. https://doi. org/10.1016/j.pt.2010.02.005

6. Caccio SM, De Giacomo M, Pozio E (2002) Sequence analysis of the b-giardin gene and development of a polymerasechain reaction-restriction fragment length polymorphism assay to genotype Giardia duodenalis cysts from human faecal samples. Int J Parasitol 32(8):1023-1030. https://doi.org/10.1016/s0020 -7519(02)00068-1

7. Certad G, Viscogliosi E, Chabé M, Cacciò SM (2017) Pathogenic mechanisms of Cryptosporidium and Giardia. Trends Parasitol 33(7):561-576. https://doi.org/10.1016/j.pt.2017.02.006

8. Costa VAN, Brener B, Fonseca ABM, Surdé AP (2018) Modification of the Alere GIARDIA Ag TEST immunochromatography KIT methodology for its use in frozen fecal sediment of 
dogs and cats. An Acad Bras Cienc 90(1):479-483. https://doi. org/10.1590/0001-3765201820160675

9. Covacin C, Aucoin DP, Elliot A, Thompson RCA (2011) Genotypic characterisation of Giardia from domestic dogs in the USA. Vet Parasitol 177(1-2):28-32. https://doi.org/10.1016/j.vetpa r.2010.11.029

10. Dado D, Montoya A, Blanco MA et al (2012) Prevalence and genotypes of Giardia duodenalis from dogs in Spain: possible zoonotic transmission and public health importance. Parasitol Res 111(6):2419-2422. https://doi.org/10.1007/s00436-012-3100-x

11. de Lucio A, Bailo B, Aguilera M et al (2017) No molecular epidemiological evidence supporting household transmission of zoonotic Giardia duodenalis and Cryptosporidium spp. from pet dogs and cats in the province of Álava Northern. Spain Acta Trop 170:48-56. https://doi.org/10.1016/j.actatropica.2017.02.024

12. Durigan M, Cardoso-Silva CB, Ciampi-Guillardi M et al (2019) Molecular genotyping, diversity studies and high-resolution molecular markers unveiled by microsatellites in Giardia duodenalis. PLoS Negl Trop Dis 12(11):e0006928. https://doi. org/10.1371/journal.pntd.0006928

13. Einarsson E, Ma' ayeh S, Svärd SG, (2016) An up-date on Giardia and giardiasis. Curr Opin Microbiol 34:47-52. https://doi. org/10.1016/j.mib.2016.07.019

14. Fantinatti M, Caseca AC, Bello AR, Fernandes O, Da-Cruz AM (2018) The presence of Giardia lamblia assemblage A in dogs suggests an anthropozoonotic cycle of the parasite in Rio de Janeiro, Brazil. Infect Genet Evol 65:265-269. https://doi.org/10.1016/j. meegid.2018.07.025

15. Feng Y, Xiao L (2011) Zoonotic potential and molecular epidemiology of Giardia species and giardiasis. Clin Microbiol Rev 24(1):110-140. https://doi.org/10.1128/CMR.00033-10

16. Geurden T, Berkvens D, Casaert S, Vercruysse J, Claerebout E (2008) A Bayesian evaluation of three diagnostic assays for the detection of Giardia duodenalis in symptomatic and asymptomatic dogs. Vet Parasitol 157(1-2):14-20. https://doi. org/10.1016/j.vetpar.2008.07.002

17. Gil H, Cano L, de Lucio A et al (2017) Detection and molecular diversity of Giardia duodenalis and Cryptosporidium spp. in sheltered dogs and cats in Northern Spain. Infect Genet Evol 50:62-69. https://doi.org/10.1016/j.meegid.2017.02.013

18. Godínez-Galaz EM, Veyna-Salazar NP, Olvera-Ramírez AM (2019) Prevalence and zoonotic potential of giardia intestinalis in dogs of the Central Region of Mexico. Animals (Basel) 9(6):325. https://doi.org/10.3390/ani9060325

19. Jaros D, Zygner W, JarosS WH (2011) Detection of Giardia intestinalis assemblages A, B and D in domestic cats from Warsaw Poland. Pol J Microbiol 60(3):259-263

20. Julien DA, Sargeant JM, Guy RA et al (2019) Prevalence and genetic characterization of Giardia spp. and Cryptosporidium spp. in dogs in Iqaluit, Nunavut Canada. Zoonoses Public Health 66(7):813-825. https://doi.org/10.1111/zph.12628

21. Kostopoulou D, Claerebout E, Arvanitis D et al (2017) Abundance, zoonotic potential and risk factors of intestinal parasitism amongst dog and cat populations: the scenario of Crete. Greece Parasit Vectors 10(1):43. https://doi.org/10.1186/s1307 1-017-1989-8

22. Kváč M, HofmannováL OY (2017) Stray cats are more frequently infected with zoonotic protists than pet cats. Folia Parasitol (Praha) 64(2017):034. https://doi.org/10.14411/fp.2017.034

23. Lalle M, Pozio E, Capelli G et al (2005) Genetic heterogeneity at the b-giardin locus among human and animal isolates of Giardia duodenalis and identification of potentially zoonotic subgenotypes. Int J Parasitol 35(2):207-213. https://doi.org/10.1016/j. ijpara.2004.10.022

24. Lebbad M, Mattsson JG, Christensson B et al (2010) From mouse to moose: multilocus genotyping of Giardia isolates from various animal species. Vet Parasitol 168(3-4):231-239. https://doi. org/10.1016/j.vetpar.2009.11.003

25. Mochizuky M, Hashimoto M, Ishida T (2001) Recent epidemiological status of canine viral enteric infections and Giardia infections in Japan. J Vet Med Sci 63(5):573-575. https://doi. org/10.1292/jvms.63.573

26. Monis PT, Mayrhofer G, Andrews RH, Homan WL, Limper L, Ey PL (1996) Molecular genetic analysis of Giardia intestinalis isolates at the glutamate dehydrogenase locus. Parasitology 112(Pt 1):1-12. https://doi.org/10.1017/s0031182000065021

27. O'Neill DG, Baral L, Church DB, Brodbelt DC, Packer RMA (2018) Demography and disorders of the French Bulldog population under primary veterinary care in the UK in 2013. Canine Genet Epidemiol 5:3. https://doi.org/10.1186/s40575-018-0057-9

28. Pan W, Wang M, Abdullahi AY et al (2018) Prevalence and genotypes of Giardia lamblia from stray dogs and cats in Guangdong, China. Vet Parasitol Reg Stud Rep 13:30-34. https://doi. org/10.1016/j.vprsr.2018.03.012

29. Piekarska J, Bajzert J, Gorczykowski M et al (2016) Molecular identification of Giardia duodenalis isolates from domestic dogs and cats in Wroclaw Poland. Ann Agric Environ Med 23(3):410 415. https://doi.org/10.5604/12321966.1219178

30. Pipiková J, Papajová I, Majláthova V et al (2018) First report on Giardia duodenalis assemblage $\mathrm{F}$ in Slovakian children living in poor environmental conditions. J Microbiol Immunol Infect 53(1):148-156. https://doi.org/10.1016/j.jmii.2018.04.007

31. Rehbein S, Klotz C, Ignatius R et al (2018) Giardia duodenalis in small animals and their owners in Germany: a pilot study. Zoonoses Public Health 66(1):117-124. https://doi.org/10.1111/ zph. 12541

32. Savioli L, Smith H, Thompson A (2006) Giardia and Cryptosporidium join the 'neglected diseases initiative'. Trends Parasitol 22(5):203-208. https://doi.org/10.1016/j.pt.2006.02.015

33. Shin JC, Reyes AW, Kim SH et al (2015) Molecular detection of Giardia intestinalis from stray dogs in animal shelters of Gyeongsangbuk-do (Province) and Daejeon Korea. Korean J Parasitol 53(4):477-481. https://doi.org/10.3347/kjp.2015.53.4.477

34. Solarczyk P, Majewska AC (2010) A survey of the prevalence and genotypes of Giardia duodenalis infecting household and sheltered dogs. Parasitol Res 106(5):1015-1019. https://doi. org/10.1007/s00436-010-1766-5

35. Sommer MF, Rupp P, Pietsch M, Kaspar A, Beelitz P (2018) Giardia in a selected population of dogs and cats in Germany diagnostics, coinfections and assemblages. Vet Parasitol 249:4956. https://doi.org/10.1016/j.vetpar.2017.11.006

36. Sulaiman IM, Fayer R, Bern C et al (2003) Triosephosphate isomerase gene characterization and potential zoonotic transmission of Giardia duodenalis. Emerg Infect Dis 11:1444-1452. https ://doi.org/10.3201/eid0911.030084

37. Štrkolcová G, Mad’ar M, Hinney B, Goldová M, Mojžišová J, Halánová M (2015) Dog's genotype of Giardia duodenalis in human: first evidence in Europe. Acta Parasitol 60(4):796-799. https://doi.org/10.1515/ap-2015-0113

38. Tangtrongsup S, Scorza V (2010) Update on the diagnosis and management of Giardia spp. infections in dogs and cats. Top Companion Anim Med 25(3):155-162. https://doi.org/10.1053/j. tcam.2010.07.003

39. Traub RJ, Monis PT, Robertson I, Irwin P, Mencke N, Thompson RC (2004) Epidemiological and molecular evidence supports the zoonotic transmission of Giardia among humans and dogs living in the same community. Parasitology 128(Pt 3):253-262. https:// doi.org/10.1017/s0031182003004505

40. The European Pet Food Industry (2019) European Fact and Figures 2019.https://www.fediaf.org

41. Uiterwijk M, Nijsse R, Kooyman FNJ (2019) Host factors associated with Giardia duodenalis infection in dogs across multiple 
diagnostic tests. Parasit Vect 12(1):556. https://doi.org/10.1186/ s13071-019-3810-3

42. Zotter EM, Bieri M, Basso W, Schnyder M (2019) Intestinal parasites and lungworms in stray, shelter and privately owned cats of Switzerland. Parasitol Int 69:75-81. https://doi.org/10.1016/j. parint.2018.12.005
43. Zygner W, Jaros D, Skowrońska M et al (2006) Prevalence of Giardia intestinalis in domestic dogs in Warsaw. Wiadomości Parazytologiczne 52(4):311-315 (in Polish) 